\section{United States still ill-prepared}

Washington

A General Accounting Office (GAO) report* lambasting the US Defense Department's efforts to improve its defensive capabilities for chemical warfare has caused a ripple in Washington. The report, delivered to Congress at the end of July and made public this month, finds that although there have been improvements in the military's defensive capabilities and ability to fight on a chemical battlefield, areas of medical doctrine and personnel training are severely deficient.

GAO initially set out to determine the adequacy of the Pentagon's preparations

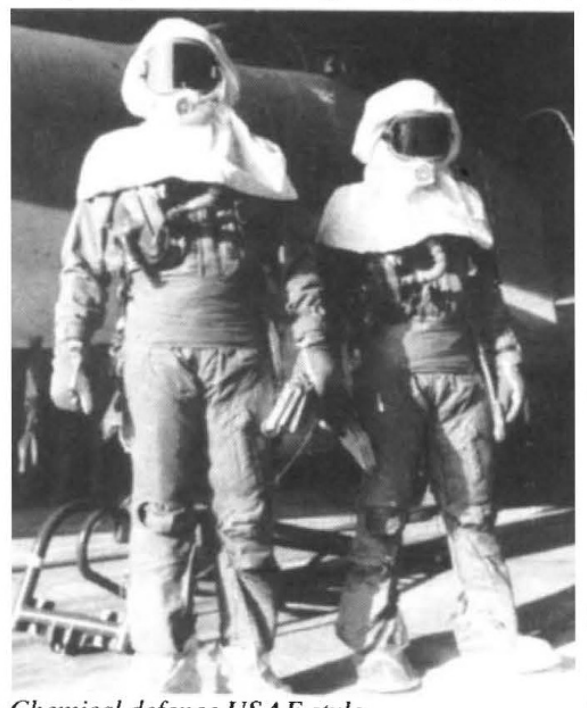

Chemical defence USAF-style

for chemical warfare. But in many cases, the report contends that the Defense Department had established no criteria for determining adequacy, so the GAO changed its focus to how far the Pentagon had come in its preparations since 1982.

There has been progress in getting defensive equipment into the field, but many problems remain. Currently the Defense Department has no antidotes against blood, blister or choking agents. Pyridostigmine, a British drug thought to be effective against all nerve agents, is just being introduced into the field. Problems continue to plague efforts to design effective protective garments. An adequate face mask has yet to be developed, and the latest suit to be used by the Navy "loses its protective qualities when it is wet". GAO has also identified problems in plans for decontaminating equipment following attack, detection of attack and availability of chemical defence equipment.

Although the Defense Department has had an active programme of research on chemical warfare defences, the GAO says the programme has been marked by "numerous delays and cancellations", and relatively few items have actually been put into the field. Funding shortages cannot be blamed.

Training procedures for using existing equipment are also inadequate, according to the GAO report. Although there has been improvement in chemical warfare training, without more frequent and realistic testing it is impossible to evaluate the military's state of readiness.

Defense Department spokesman Major Randy Morger says the Pentagon "agrees with the bottom line" of the GAO report. Morger says thousands of millions of dollars could be poured into chemical defences, but no fighting force will be truly effective using defence measures alone. Morger acknowledges that GAO has
Biotechnology patents

\section{Washington}

Cetus and Genentech, two of the most venerable biotechnology companies in the United States, are bracing themselves against separate patent challenges raised this month over some of their most promising products. Disputes have erupted between Cetus and Amgen over several forms of interleukin-2 while HoffmanLaRoche, with the California-based Hormone Research Foundation, is contesting Genentech's claim to recombinant human growth hormone.

These suits are among the first generation of patent battles in biotechnology and, as such, will have few precedents to guide them. But an appeals court's decision last week to restore patent privileges to Hybritech for the sandwich assay protocol seems to betoken fair wind for the patent-holder, foul for the challenger.

In a move akin to a pre-emptive strike, Amgen announced late last month that it was seeking a ruling that it is not violating three of Cetus's four interleukin-2 patents. Although a Cetus spokesperson declares that, before Amgen's action, the company "had no intention of bringing a lawsuit against Amgen", Cetus joined the fray two weeks later claiming infringement. Part of the controversy concerns a form of interleukin-2 sold by Amgen which Cetus claims is identical to one of its own patented interleukins.

Even more heat surrounds the pure forms of interleukin-2 Cetus is producing for clinical trials conducted by the National Institutes of Health. Johnson \& Johnson and Hoffman-LaRoche, both in New Jersey, are trailing with their own trials, and Amgen supplies a very pure form of interleukin-2 to Johnson \& Johnson. Cetus does not know the composition of Amgen's product, but believes that its two patents on purified interleukin en- pointed out some problem areas, and there may even be others that GAO has missed. But he argues that an effective retaliatory capability is necessary to deter chemical attack.

While the Pentagon appears willing to take criticism for its defensive efforts, it was not so sanguine about suggestions that the centrepiece of its new offensive capability, the Bigeye bomb, might be flawed (see Nature 321, 717; 1986). The Pentagon took great pains to refute criticisms of Bigeye. But Eleanor Chelimsky, director of GAO's division of programme evaluation and methodology, says the defensive programme is "really in bad shape, but it doesn't seem to upset anyone."

Joseph Palca

* Chemical Warfare: Progress and Problems in Defensive Capabilities. GAO/PEMD-86-11. Washington, DC 1986.

\title{
New rash of legal suits ahead
}

compass any product pure enough to meet Food and Drug Administration standards for clinical trials. The company will not comment on its position with regards to Roche.

Roche, meanwhile, has been trying to wrest a licensing agreement from Genentech for human growth hormone. Roche, not Genentech, claims to possess the original patent on "synthetic human growthpromoting . . . hormone," issued in 1974 to C.H. Li, a University of California scientist who performed the first organic synthesis. Li filed his patent two years before Cohen and Boyer patented the notion that bacterial plasmids might be engineered to generate specific proteins; he formed the Hormone Research Foundation to further his studies.

Hoffman-LaRoche gained exclusive rights to Li's patent in 1982, hoping to capitalize on the fruits of recombinant work on growth hormone by signing licensing arrangements with the purveyors. Genentech, however, has balked at this strategy on the grounds that "synthetic" does not include, and could not have anticipated, recombinant-DNA products. Two weeks ago, Genentech, which worked closely with Roche on alphainterferon, announced its intention to defend its position.

Both disputes will take years and millions of dollars to resolve and, according to one industry analyst, are just the first blush of a burgeoning harvest. Iver Cooper, author of Biotechnology and the Law, thinks a dozen such lawsuits will be pending by the end of the decade. And since Hybritech's appeal proved victorious, patent-holders may be willing to press cases beyond the first ruling. The scope and interpretation of patent law on recombinant-DNA products will have to be defined amidst the crossfire. Karen Wright 